\title{
SOSIALISASI UPAYA BELA NEGARA MELALUI PENERAPAN PROTOKOL KESEHATAN COVID-19 PADA SANTRIWAN DAN SANTRIWATI TPA MASJID BAITUL JAMAAH BATU KUWUR DESA SUKARARA
}

\author{
Oleh \\ Uwi Martayadi ${ }^{1)}$ \& Dyah Indraswati ${ }^{2)}$ \\ ${ }^{1}$ Program Studi Pariwista, Sekolah Tinggi Pariwisata Mataram \\ ${ }^{2}$ PGSD, FKIP, Universitas Mataram \\ Email: ${ }^{1}$ uwimartayadistp@ gmail.com \& 2 dyahindraswati@unram.ac.id
}

\begin{abstract}
The emergence of Coronavirus Disease 2019 (Covid-19) has caused countries around the world including Indonesia to experience problems in various aspects of life because the virus can attack anyone of any age (elderly, adult, children, infants, or pregnant women). The presence of this virus creates a new habit that gives rise to the term new normal with health protocols (wearing masks, keeping distance, and washing hands with soap in running water). Many people, santriwan and santriwati children have not implemented health protocols. The purpose of the service is to provide an understanding of the importance of applying Covid-19 health protocols to santriwan and santriwati TPA Baitul Jamaah Batu Kuwur Mosque to prevent transmission to others. The stage in this devotion began from communication conducted with ustadz who taught at the TPA Masjid Baitul Jamaah Batu Kuwur, asking permission to conduct observation and socialization. The next stage is observation, identifying problems by observing during landfill activities. The last stage is socialization, providing an understanding of the importance of state defense efforts through the application of health protocols. The results of the service showed that santriwan and santriwati did not implement health protocols during landfill activities because of their incomprehension about Covid-19. The socialization made Santriwan and santriwati's understanding increase in the implementation of Covid-19 health protocols.
\end{abstract}

Keywords: Socialization; State Defense \& Health Protocol

\section{PENDAHULUAN}

Pada dasarnya ketahanan sebuah bangsa sangat diperlukan dalam rangka menjamin, memelihara, memperkuat, mempertahankan, dan menghadapi berbagai macam ancaman yang datang dari dalam dan luar negeri termasuk ancaman wabah pandemi Coronavirus Disease 2019 (Covid-19) yang sedang melanda dunia termasuk Indonesia. Dunia dihantui ketidkpastian dikarenakan wabah pandemi Covid-19 yang melumpuhkan pergerakan manusia dengan berdiam diri di rumah dan melumpuhkan pula berbagai macam sektor diantaranya pariwisata, manufaktur, ekonomi, transportasi,sosial, pangan dan lainlain.

Ketidakpastian kapan Covid-19 ini akan berakhir membuat masyrakat dunia termasuk Indonesia menjadi panik. Pemerintah Indonesia dalam rangka untuk mengantisipasi, melindungi, dan mengurangi penderita Covid19 memberlakukan beberapa kebijakan diantaranya membatasi aktifitas keluar rumah, kegiatan sekolah dirumahkan, bekerja dari rumah, bahkan kegiatan ibadahpun dirumahkan (Sumarni, 2020).

Upaya untuk menjaga keslamatan rakyat adalah bagian dari bela negara. Sesuai dengan amanah UUD 1945 pasal 27 ayat (3): "Setiap warganegara berhak dan wajib ikut serta dalam upaya pembelaan negara," dan pasal 30 ayat (1): "Tiap-tiap warga negara berhak dan wajib ikut serta dalam usaha pertahanan dan keamanan negara" Bela negara tidak harus dengan mengangkat senjata dan tidak hanya dilakukan oleh TNI semata. Namun, bela negara bisa dilakukan oleh setiap warga negara Indonesia sesuai dengan profesi masing- 
masing. Dalam rangka mengatasi laju penyebaran covid-19 diperlukan kesadaran dan peran dari semua lapisan untuk saling menjaga dan saling mengingatkan satu sama lain (Nurhalimah, 2020).

Oleh karena itu, harus ada kerjasama yang baik antara Pemerintah, pemerintah daerah, dan warga negara (masyarakat) dalam rangka mengatasi laju penyebaran covid-19 ini. Ketika Pemerintah mengeluarjkan kebijakan dimana kebijakan tersebut disparitas dengan Pemerintah Daerah terkait penanganan Covid19 tentu saja akan menimbulkan diskursus di tengah masyarakat (Wadi, 2020). Maka perlu adanya persamaan perspsektif dengan jalan membuka ruang diskusi (musyawarah mufakat) agar tidak terjadi kesalahfahaman dalam penerapan kebijakan pemerintah pusat dan pemerintah daerah.

Kita semua ingin menjaga dan membela negara Indonesia dari serangan Covid-19 maka perlu untuk saling ingat-mengingatkan, nasehat-menasehati agar sama-sama menerapkan protokol kesehatan Covid-19 yaitu dengan selalu mencuci tangan dengan sabun dan air mengalir atau handsanitizer, menjaga jarak minimal 1 meter, dan selalu menggunakan masker ketika keluar rumah (bepergian). Hal ini penting dilakukan dalam rangka mengurangi resiko terjadinya penularan Covid-19 (Prayitno et al., 2020).

Agar protokol kesehatan covid-19 bisa terlaksana dengan baik maka Pemerintah Pusat, Pemerintah Daerah, dan semua elemen secara bersama-sama mensosialisasikan kepada masyarakat bawah untuk mengikuti aturan yang diberlakukan oleh Pemerintah demi keselamatan bersama, karena masyarakat bawah masih banyak yang tidak faham sehingga mengabaikan protokol kesehatan Covid-19. Sosialisasi ini dirasa sangat penting mengingat penyebaran Covid-19 sangat cepat bisa melalui mulut, hidung dan mata manusia apabila terjadi kontak langsung (Syafrida, 2020).

\section{METODE PELAKSANAAN}

Kegiatan sosialisasi upaya bela negara melalui penerapan protokol kesehatan Covid19 pada santriwan dan santriwati TPA Masjid Baitul Jamaah Batu Kuwur dilaksanakan dengan tahapan komunikasi, observasi, dan sosialisasi. Sebelum kegiatan sosialisasi dilakukan, terlebih dahulu pengabdi melakukan komunikasi dengan meminta izin kepada ustadz TPA Masjid Baitul Jamaah Batu Kuwur. Setelah mendapat izin, kemudian melakukan observasi dengan mengidentifikasi permasalahan dengan cara mengamati pada saat pembelajaran TPA. Setelah dilakukan observasi dan identifikasi masalah maka pengabdi berdiskusi lagi dengan ustadz TPA Masjid Baitul Jamaah Batu Kuwur untuk menentukan hari/tanggal sosialisasi, dan disepakati pada hari Rabu, 23 Desember 2020 pukul 16.00-17.00 WITA.

\section{HASIL DAN PEMBAHASAN}

Kegiatan pengabdian ini dilakukan dalam rangka menjalankan Tri Darma Perguruan Tinggi sebagai dosen, yaitu melakukan Pengajaran, Penelitian, dan Pengabdian kepada masyarakat. Pengabdian tentang sosialisasi upaya bela negara melalui penerapan protokol kesehatan Covid-19 pada santriwan dan santriwati TPA Masjid Baitul Jamaah Batu Kuwur dilakukan untuk memberikan pemahaman agar santriwan dan santriwati tahu bagaimana menerapkan protokol kesehatan Covid-19 yaitu memakai masker, menjaga jarak, dan mencuci tangan dengan sabun di air yang mengalir. Selama aktivitas TPA tidak ada penerapan protokol kesehatan yang dijalankan hal ini karena ketidaktahuan para santri tentang hal tersebut.

Dalam pengabdian ini ada beberapa tahapan yang telah dilalui mulai dari komunikasi, observasi, dan sosialisasi. Pertama, komunikasi. Komunikasi ini sangat penting dilakukan sebagai pembuka jalan untuk bisa melaksanakan tahap selanjutnya yaitu observasi dan sosialisasi. Tanpa adanya komunikasi maka interaksi tidak akan terjadi antara kedua belah pihak yaitu pihak pengabdi dan pihak ustadz TPA Masjid Baitul Jamaah 
Batu Kuwur (Dyah Indraswati, Husniati, Ida Ermiana, Arif Widodo, 2020). Pada tahap ini pengabdi melakukan komunikasi secara inten dengan ustadz TPA secara langsung maupun via telephone. Dengan komunikasi yang baik, maka disepakati hari/tanggal untuk melakukan observasi dan sosialisasi.

Kedua, observasi. Observasi dilakukan pada hari Selasa, 22 Desember 2020. Observasi ini dilakukan untuk mengidentifikasi masalah yang terkait dengan penerapan protokol kesehatan Covid-19. Hasil observasi menunjukkan bahwa tidak ada yang menerapkan protokol kesehatan di TPA Masjid Baitul Jamaah Batu Kuwur. Hal ini dikarenakan orang tua para santri yang tidak mengerti tentang Covid-19 karena tingkat pendidikan orang tua mereka masih sangat minim. Para orangtua juga menganggap di kampung Batu Kuwur aman dari Covid-19 karena tidak ada pendatang dari luar desa sehingga protokol kesehatan Covid-19 diabaikan. Santriwan dan santriwati TPA Masjid Baitul Jamaah Batu Kuwur dalam melaksanakan aktivitas belajarmengajar mengabaikan protokol kesehatan termasuk ustadz yang mengajar di TPA tersebut.

Ketiga, sosialisasi. Setelah komunikasi dan observasi dilakukan maka inti dari pengabdian ini yaitu melakukan sosialisasi dengan tema "upaya bela negara melalui penerapan protokol kesehatan Covid-19 pada santriwan dan santriwati TPA Masjid Baitul Jamaah Batu Kuwur Desa Sukarara". Sebelum sosialisasi dimulai santriwan dan santriwati dipersilahkan untuk duduk rapi terlebih dahulu agar penyampaian materi sosialisasi bisa diterima dengan baik. Sosialisasi dilaksanakan pada hari Rabu, 23 Desember 2020 Pukul 16.00-17.00 WITA di Masjid Baitul Jamaah Batu Kuwur Desa Sukarara.

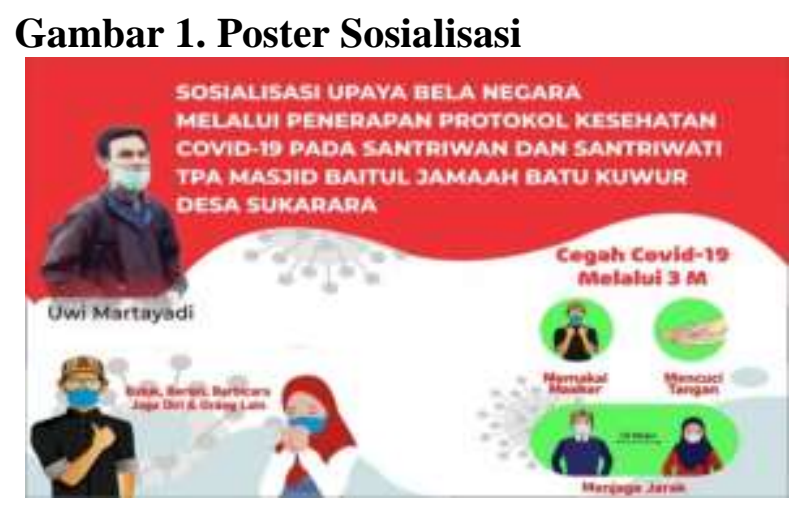

Gambar 2. Pelaksanaan Sosialisasi

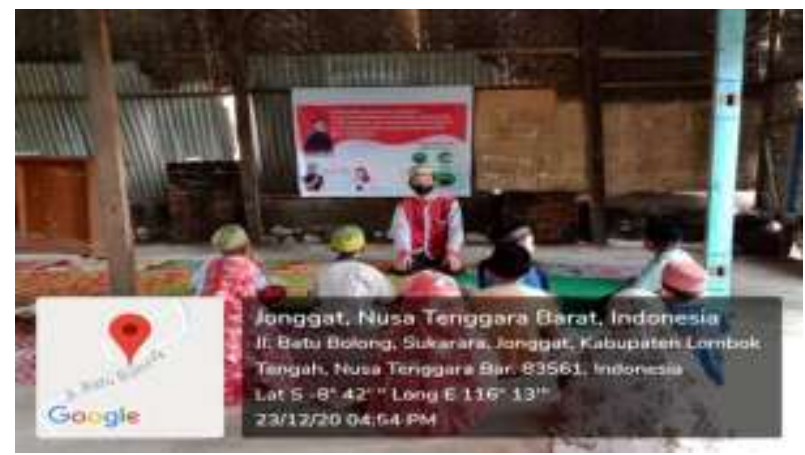

Materi sosialisasi disampaikan oleh Uwi Martayadi, M.Pd merupakan salah satu dosen Sekolah Tinggi Pariwisata Mataram. Peserta sangat antusias mengikuti kegiatan sosialisasi karena baru pertamakali ada kegiatan seperti itu. Pada saat penyampaian materi sering diselingi dengan candaan sehingga membuat santriwan dan santriwati terhibur. Inti dari materi sosialisasi yang disampaikan ada dua yaitu bela negara dan penerapan protokol kesehatan Covid-19. Bela negara bisa dilakukan oleh semua warganegara termasuk santriwan dan santriwati TPA Masjid Baitul Jamaah Batu Kuwur, tidak mesti harus menjadi TNI/angkat senjata untuk berperang, tetapi dengan mengikuti protokol kesehatan yang ada berarti sudah menyelamatkan diri sendiri dan orang lain dari marabahaya, dan itu juga merupakan bagian dari upaya bela negara.

Pada saat penyampaian materi bahasa yang digunakan adalah bahasa yang sederhana namun mudah dimengerti. Covid-19 jangan sampai disepelekan karena Covid-19 sudah menginfeksi ribuan masyarakat dunia (Arnaz Anggoro Saputro, Yudi Dwi Saputra, 2020). Oleh karena itu, penerapan protokol kesehatan harus diajarkan pada anak TPA, mereka yang 
masih polos dan belum terlalu faham tentang Covid-19 perlu untuk mendapatkan pengetahuan dasar agar terhindar dari penyakit tersebut. Tentu hal ini juga butuh dukungan dari orang tua, ustadz yang mengajar di TPA Masjid Baitul Jamaah Batu Kuwur, dan semua lapisan masyarakat. Oleh karena itu, sangat penting untuk mengadakan sosialisasi pada santriwan dan santriwati TPA Masjid Baitul Jamaah Batu Kuwur dalam rangka untuk mencegah penyebaran Covid-19 dan menumbuhkan kesadaran untuk mengikuti protokol kesehatan memaki masker, menjaga jarak, dan mencuci tangan dengan sabun di air yang mengalir atau menggunakan hand sanitizer.

Ketiga hal tersebut merupakan kebiasaan baru bagi masyarakat dunia pada umumnya, dan santriwan santriwati TPA Masjid Baitul Jamaah Batu Kuwur pada khususnya. Namun, disaat pandemi seperti saat sekarang ini perubahan perilaku tersebut memang memerlukan waktu penyesuaian dengan masyarakat tetapi lama-kelamaan kebiasaan baru tersebut akan menjadi akrab dengan masyarakat karena mau tidak mau ketiga hal tersebut merupakan kunci utama untuk mencegah penyebaran Covid-19. Maka penting sosialisasi ini dilakukan untuk melindungi diri sendiri dan orang lain dari penyebaran Covid19 yang begitu ganas. Penerapan protokol kesehatan ini harus dilakukan secara benar, karena kalau penerapannya kurang tepat maka dapat membuka celah/peluang penyebaran Covid-19.

Penerapan protokol kesehatan Covid-19 merupakan bagian dari usaha bela negara. Sikap dan tindakan warganegara yang dilandasi rasa cinta terhadap bangsa dan negara Indonesia, rela berkorban dalam menghadapi berbagai ancaman dari dalam maupun dari luar yang membahayakan keselamatan bangsa dan negara (Prayitno et al., 2020). Masyarakat Indonesia sudah banyak yang menjadi korban dari Covid-19 ini, maka menjadi tugas bersama untuk saling melindungi satu sama lain dengan menerapkan protokol kesehatan secara benar dan disosialisasikan ke masyarakat umum termasuk ke TPA.

\section{PENUTUP}

\section{Kesimpulan}

Sebagai upaya untuk mengurangi penyebaran Covid-19, maka pengabdi melakukan sosialisasi upaya bela negara melalui penerapan protokol kesehatan pada santriwan dan santriwati TPA Masjid Baitul Jamaah Batu Kuwur Desa Sukarara. Santriwan dan Santriwati dipilih karena mereka masih anak-anak dan cenderung mengabaikan protokol kesehatan sehingga potensi penyebaran Covid-19 memiliki peluang yang cukup besar pada diri mereka. Jika Pemerintah dan masyarakat serentak menerapkan 3M (memakai masker, menjaga jarak, dan mencuci tangan dengan sabun di air mengalir) maka itulah yang menjadi kunci penekan penyebaran Covid-19 dan itu adalah bagian dai upaya bela negara yang bisa dilakukan oleh semua warganegara Indonesia.

\section{DAFTAR PUSTAKA}

[1] Arnaz Anggoro Saputro, Yudi Dwi Saputra, G. B. P. (2020). Analisis Dampak Covid-19 terhadap Kesadaran Masyarakat dalam Penerapan Protokol Kesehatan. 3(2), 81-92.

[2] Dyah Indraswati, Husniati, Ida Ermiana, Arif Widodo, M. A. M. (2020). Pengaruh Kepercayaan Diri dan Kemampuan Komunikasi Terhadap Kemampuan Public Speaking Mahasiswa PGSD. 19(1), 1-15.

[3] Nurhalimah, N. (2020). Upaya Bela Negara Melalui Sosial Distancing dan Lockdown untuk Mengatasi Wabah Covid19 (Efforts to Defend the Country Through Social Distancing and Lockdown to Overcome the COVID-19 plague). SSRN Electronic Journal, 6. https://doi.org/10.2139/ssrn.3576405.

[4] Prayitno, S. A., Pribadi, H. P., Ifadah, R. A., Studi, P., Pangan, T., Pertanian, F., Fisioterapi, P. S., \& Kesehatan, F. (2020). Dedikasimu (Journal of Community Service) Volume 2, Nomor 3, September 2020 Peranserta dalam Melaksanakan Protokol Pencegahan Penyebaran Corona Virus Disiase (Covid-19) pada 
Masyarakat. Dedikasi (Journal of Community Service), 2(3), 504-510.

[5] Sumarni, Y. (2020). Pandemi Covid-19: Tantangan Ekonomi dan Bisnis. Al-Intaj Jurnal Ekonomi Dan Perbankan Syariah, 6(2), 46-58.

[6] Syafrida, S. (2020). Bersama Melawan Virus Covid 19 di Indonesia. SALAM: Jurnal Sosial Dan Budaya Syar-I, 7(6). https://doi.org/10.15408/sjsbs.v7i6.15325.

[7] Wadi, R. (2020). Konstitusionalitas Pemerintah Daerah dalam Menetapkan Kebijakan Lockdown pada Penananganan Covid-19. SALAM: Jurnal Sosial Dan Budaya Syar-I, 7(5). https://doi.org/10.15408/sjsbs.v7i5.15319. 
HALAMAN INI SENGAJA DIKOSONGKAN 